\title{
ENVIRONMENTAL IMPACT STUDIES OF CHROME ROLLERS USED BY COTTON ROLLER GINNING INDUSTRIES AND DESIGN AND DEVELOPMENT OF POLLUTION FREE CHROME LESS RCF ROLLERS
}

\author{
Gurumurthy Vijayan Iyer, \\ MNM Jain Engineering College, \\ 36, Venkatesh Nagar Main Road, \\ Virugambakkam, Chennai-600 092, \\ INDIA
}

\author{
Nikos E. Mastorakis \\ WSEAS European Office \\ Agiou Ioannou Theologou 17-13, \\ 15773, Zografou, Athens, \\ GREECE \\ mastor@wseas.org \\ http://www.wseas.org/mastorakis
}

\begin{abstract}
This paper realizes the hazards of chromium contamination and pollution caused by the use of Chrome Composite Leather-Clad (CCLC) rollers commonly used in cotton roller ginning industries and attempts to eliminate the chromium contamination and pollution during the complete process. The cotton roller ginning process is the mechanical separation of cotton fibres from their seeds by means of one or more rollers to which fibres adhere while the seeds are impeded and struck off or pulled loose. Most of the cotton ginning operations are done using roller gins. The roller coverings contain about 18000 to $30000 \mathrm{mg} / \mathrm{kg}(\mathrm{ppm})$ as total chromium of trivalent and hexavalent forms which are toxic on human health. When the seed-cotton is ginned, the ginned lint cotton adsorbs with it about 140 to $1990 \mathrm{mg} / \mathrm{kg}$ (ppm) as total chromium of trivalent and hexavalent forms. Cotton dust is a good adsorbant of $\mathrm{Cr}$ (III) and $\mathrm{Cr}$ (VI) from chrome Specific Dust (CSD) being powdered during ginning operation. Due to persistent rubbing of CCLC roller over the fixed knives, this carries with it 25 to $100 \mathrm{mg} / \mathrm{kg}$ (ppm) which according to eco-standards for yarn and fabric, should not be more than $0.1 \mathrm{mg} / \mathrm{kg}(\mathrm{ppm})$. The chromium contamination in cotton seeds and oil are 125 to $300 \mathrm{mg} / \mathrm{kg}$ (ppm) and corresponding eco-standard is $2 \mathrm{mg} / \mathrm{kg}$. This causes chromium poisoning lead to skin disorders and liver damage on human and animal health. Subsequently the same or less amount is carried till textile of effluent which according to environmental standards should not be more than $2 \mathrm{mg} / 1$. The traces found contain hexavalent chromium being adsorbed from chromiumcontaminated lint, yarn, fabric, seeds and by products and textile effluent.

The chromium concentration in suspended particulate matter (SPM) is $1994 \mathrm{mg} / \mathrm{kg}$ (ppm), which according to environmental standard should not be more than $2 \mathrm{ppm}$. The
\end{abstract}


chromium content in respirable suspended particulate matter (RSPM) is $150 \mathrm{ppm}$. Gin and mill workers are exposed to this chromium pollution, is susceptible to health hazards. Toxic effects are produced by prolonged contact with airborne or solid or liquid chromium compounds even in small quantities. The three pollutants, viz., cotton dust, chromium and leather powder and/or other foreign matter, under favourable conditions of sunlight (photo energy), humidity, temperature and air movement interact and produce chrome specific dust (CSD) which is a serious pollutant due to synergistic interacting function. A human health survey is made among the workers of the cotton ginning industry and the people exposed to the contamination and pollution such as the children with working mother in order to study the occupational health and safety of the industry. Chromium poisoning is observed in animal liver due to the consumption of contaminated cotton seeds. To offset this problems, pollution-free rubberized cotton fabric rollers or eco-friendly rollers for commercial studies have been designed, fabricated and experimented in rollers gins. This controls and nullifies chromium contamination and pollution during the complete process. Cotton technological parameters are well proved for commercial acceptance.

\section{Introduction}

The cotton roller ginning process may be briefly defined as the mechanical separation of cotton fibres from their seeds by means of one or more rollers to which fibres adhere while the seeds are impeded and struck off or pulled loose. The principle of this roller ginning process was invented by McCarthy. The method is holding the fibres by adherence over the surface of leather rollers and removing the seed-cotton. Figure-1; Configuration of Cotton Roller Ginning Process. Since the semi-finished chrome leather washers contains 3 to $4 \%$ as total chromium and are being used by roller ginning industries in India, Africa, Tanzania and Egypt attention has been drawn to view the contaminating and polluting aspects during the complete process. The chrome specific dust pollutes the gin-house air and the cotton processing workers suffer from chromium bound diseases and physiological disorders. The chromium adsorbed into lint causes allergic symptoms, cancer incidence, brain damage, chronic ulceration and perforation of nasal septums to cotton processing workers. Toxic effects are produced by prolonged contact with airborne or solid or liquid chromium contamination and pollution even in small quantities. 
Cotton seeds get contaminated with chromium from the source. Present work is aimed to identify and study the environmental and health related problems faced with currently used Chrome Composite Leather-Cladding (CCLC) rollers. Some experimental results of chromium analysis and relevant eco-standards, quantity of respirable and suspended particulate matter samples, health survey observations and cotton technological reports of eco-friendly lint and chrome contaminated lint are presented for assessing the hazards of chromium contamination of lint, yarn and fabrics and air pollution problems due to chrome specific dust (CSD). After realizing the hazards of chromium contamination inlint, seed, yarn, fabric and textile effluent and air pollution problems due to chrome specific dust in ginning and textile environment, there is a need to eliminate contamination and pollution due to chromium at the source that is at cotton ginning process being done in these countries.

\section{Description and Performance of CCLC Rollers in DR gins}

The roller is the major component of DR gin. The gin roller length varies from 1025 to $1148 \mathrm{~mm}$ with a diameter varying from 178 to $180 \mathrm{~mm}$ suitable for operation. The roller consists of 78 to 80 numbers washer disks. Each washer disk is made of dimensions having the diameter $180 \mathrm{~mm}$ and thick $1 \mathrm{~mm}$ comprising of 18 numbers CCLC flaps stitched and bonded together. Basic Chromium Sulphate (BCS) $\mathrm{Cr}(\mathrm{OH})$ $\mathrm{SO}_{4} \mathrm{nH}_{2} \mathrm{O}$ and impure chromate having 45-50\% basicity are used during chrome leather tanning process for making such CCLC flaps. The various unit operations involved in making washers to final shape of the roller are (i) The washers are filled in a steel shaft having square cross section of $50 \mathrm{~mm}^{2}$ or hexagonal section of $50 \mathrm{~mm} \mathrm{E} / \mathrm{E}$ to form a roller, (ii) The filled washers are compressed to a pressure of $14 \mathrm{~kg} / \mathrm{cm}^{2}$ by using a conventional pressing machine. The roller is to be pressed on both sides by adding required number of washers on each side, (iii) The pressed roller is turned and finished to diameter $180 \mathrm{~mm}$ in a center lathe, (iv) Spiral grooves are made on the surface of the finished rollers; The finished roller is ready for grooving operation by using band saw; initially by marking ' $U$ '-shaped spiral grooves, fixing in the grooving machine and lastly spiral grooves are made on the roller surface by band saw or circular saw cutting machine.

The ginning efficiency primarily depends upon the surface speed of the roller and number of working strokes on the moving knife (Shete,D.G., et.al., 1993). While operation of these rollers in the ginning machines, the rate of ginning goes on declining 
when the roller diameter is reduced. At the end of cotton season having three months duration, that is after the diameter is reduced to $114 \mathrm{~mm}$, the washers are removed from the shaft. Again the new washers are recovered and cladded in shaft. The worn out and consumed washer disks after considerable period of usage for about three months .

\section{Environmental Impacts of CCLC Rollers}

Environmental impacts of CCLC rollers are assessed from the pollutants viz., cotton dust and chrome specific dust (CSD) in the mill atmosphere. Their sources and health effects are briefly described below.

The cotton dust released in the ginning process is a complex and variable mixture of cotton fibres, undeveloped ovules, cotton plant debris including twigs, bract and pericarp particles left after the ginning process together with soil particles, bacteria, fungi and residues from pesticides. The visible and invisible dust in the mill atmosphere is known as ' $F l y$ '. The ambient air particles of about $2.5 \mu \mathrm{m}$ are classified as cotton dust in ginning environment. Byssinosis is a disease due to the inhalation of cotton dust over long period of time (Shirley Vol. II, 1982). It is a permanent disabling lung disease. The symptom is chronic cough ending in chronic bronchitis (respiratory disorder). India has a large number of ginning and textile mills employing $48 \%$ of all the factory workers (Rao, M.N., 1995). About 55\% of mill workers suffer from byssinosis disease (Rao, C.S., 1995).

As per the rough estimate during field survey/discussions with ginning industry management, presently, there are about 2,13,000 CCLC rollers, which comprise of $1,70,40,000$ CCLC washers are used for a cotton season of three months in our country. There are about 7,60,000 people working in roller ginning industries in India.

Due to the persistent rubbing action between CCLC rollers and stationary knives in ginning machines, they are wearing out constantly and exorbitantly contaminating the ginned lint cotton with chromium and gets permanently coated during the ginning process. CSD production during this process is the major environmental chromium contamination and pollution problem from roller ginning industries. It is mentioned that contamination of cotton by the foreign matter other than field originating trash is the serious problem. Lint cotton and cotton dust are the adsorbents of chromium from CSD emission. Thus, chromium is adsorbed in lint cotton, spun yarns, woven fabrics in macro level. During the wet textile processing stage, the concentration of chromium in the effluent is precipitated in micro amount. 
The chromium concentration is reduced in micro amount during beating operations, blow room mechanical cleaning and carding process. It is permanently coated with spun yarns and woven fabrics in considerable amount against the safe limits of $0.1 \mathrm{ppm}$ prescribed by eco-standards. Cotton seeds are an important source of edible oil. The ginned cotton seeds are also contaminated with chromium in huge concentration, thus polluting edible oil. Chromium contaminated cotton seeds cause chromium poisoning lead to skin disorders, liver damage on human and animal liver. Oil cakes consumed by animals were found with chromium poisoning diseases.

Chromium in CSD and contaminated cotton products acts on human in three ways, viz., (1) local action as dermatitis or absorption through skin, (2) direct inhalation and (3) ingestion or absorption into stomach (Morton Lippman, 1991). Toxic effects are produced by prolonged contact with airborne, solid or liquid chromium compounds even in small quantities because of their properties viz., carcinogenecity, mutagenecity and corrosiveness (Sujana, M.G., et.al.,1997). Complications do arise due to the reducing nature of these chromium traces that affect organic tissues of body.

The air pollution due to CSD and cotton dust, which is responsible for synergistic (augmentative) health complications of chromium based diseases and byssinosis diseases on ginning industry workers. Almost most of the mills in India are not provided with dust control systems. Nor they provide personal protection devices to the workers. It is mentioned that the ginning industries are located in and around cotton growing areas and employ women in the age group of 21 to 40 years for menial jobs and male workers in the age group of 18 to 50 years. The women often come along with their children for performing their jobs, like (i) feeding seed-cotton (or kapas), (ii) collecting the lint cotton, seed and floor sweeping, (iii) cleaning and grading the seedcotton and (iv) light activities. The children are exposed directly to CSD. The health effects and reports of the workers has not come out into public, because (i) almost all the workers are not in regular employment, (ii) the cotton ginning industry functions seasonally for 6-8 months in semi-arid zones and 8-10 months in rain fed areas in an year, (iii) the workers are reluctant to go for their medical checkup because of their negligence and fear and (iv) they are economically not sound enough to go for their medical treatments.

Based on the environmental impacts of CCLC rollers in roller ginning industries, the first part of the present study pertains to assess environmental chromium pollution during the cotton ginning process. 


\section{Basis of Design and Development of Eco-friendly Chrome Less Roller for Cotton Roller Gins}

In conventional ginning process, CCLC rollers emits tremendous chromium in ginning environment due to constant dust-producing, grinding action which contaminates the cotton and its products. This also causes air pollution in the mill environment. An exhaustive study is needed for the development of eco-friendly chrome less roller, which can be an alternative to the existing CCLC rollers.

An exhaustive material studies are done for the suitable material's selection of the gin rollers which are made of Walrus animal skin, Spider tuck packing, coir-board, rubber packing, metal cylinder, rubber roll, fabric and rubber packing, leather, cotton, rubber and cork, plastics and fluorinated ethylene propylene. The peculiar gripping action or adherence of the cotton fibres to the roller surface is considered while designing the rollers. The leather surfaces possess interfibrillary action, which enables to adhere the fibre on the surface. This particular property is studied extensively for the different materials and combination of different materials so as to design and fabricate laboratory gin chrome less rollers for gin roller experimentation device (GRED) and prototype eco-friendly chrome less rollers for existing DR gins. One of the associated objectives of laboratory studies are to define the physical properties of a roller covering material which contributes to its energy consumption, ginning rate potential, ecofriendly parameters, cotton technological parameters, mechanical engineering analysis, wear resistance properties, heat proof capacity and to search better roller covering materials.

\section{Materials and Methods}

For the present study, roller wearing and compaction rate study were conducted in Roller ginning industries at Belgaum, India for the cotton seasons 1996-1997 to 1998-2000 and 2001-2002. The roller gins are adjusted using spacers as per the standards. Grooving is done regularly at the start of each shift as per cotton varieties. To study the heavy metal as total chromium $\mathrm{mg} / \mathrm{Kg}(\mathrm{ppm})$ in cotton lint samples, seed samples, seed-cotton samples, CCLC roller samples, CCLC roller samples collected during grooving operation, soil samples from the region of investigation is made, root 
of the plant for bio-availability, fibre, yarn, fabric samples, textile effluent samples, the standard American Public Health Association (APHA) method is followed for chromium (as total and hexavalent) analysis using Atomic Spectrometer (AAS). Respirable and suspended particulate matter quantity in gin house air are monitored using High Volume Air Sampler (HVAS) with cascade impactor with appropriate glass fibre filters. The quantity of pollutants are collected in HVAS as 8 hours basis and analysed for chromium. The worker dose and exposure time are found using the personal sampler. Cotton technological parameters are tested in High Volume Instrument (HVI) and Scanning Electron Microscope (SEM) for chrome roller ginned lint and eco-friendly roller ginned lint and given in Table 2.

A health study is conducted by the author at Guntur, Bailhongal, Sendwa, Surendranagar, India, Tanzania and other countries, where maximum number of ginning factories are situated to survey the health effects and occupational health hazards. In view of the environmental problems existing with the present CCLC rollers employed in ginning industries and subsequent to literature survey made, it was decided to develop environmentally free alternatives. The details are discussed henceforth.

The ginning investigations were carried out at Central Institute for Research on Cotton Technology (CIRCOT), Mumbai. The laboratory rollers for GRED were designed and fabricated at Calcutta at a local manufacturing firm. Experiments with the designed rollers were conducted at CIRCOT, Mumbai along with the cotton technological parameters. After the initial tests, pilot model rollers were designed and fabricated which were tested in ginning factories at Bailhongal and Sendhwa. Environmental analysis was done in Centre of Mining Environment, Indian School of Mines, Dhanbad, and Eco-Textile laboratory, Mumbai. Mechanical properties were analyzed in various mechanical engineering laboratories. Pilot model 'System after Modification' was demonstrated in a ginning industry at Bailhongal.

\section{Results and Discussions}

An experiment is conducted to find out the wearing and compactness rate of CCLC rollers used by roller ginning industries for a season lasting three months. At the start of season the diameter of rollers are $180 \mathrm{~mm}$. At the end of season the roller dimensions are noted at left, middle and right positions for all the roller gins in the factory, that is 18 ginning machines. The results are presented (Table 2). Apart from the 
wear and tear rate, the table expresses the quantity of pollutants generating during the operation, viz. chromium, leather powder, cotton dust and chrome specific dust. It is found that the wearing rate is $0.033 \mathrm{~mm} /$ hour and the percentage material removed per roller $43.8 \%$. The final diameter at the end of study is nearing $140 \mathrm{~mm}$. The compaction rate is $0.050 \mathrm{~mm} /$ hour. Figure-5 , Graph showing wearing rate of Dust-producing grinding of CCLC roller and RCF roller.

Chromium analysis report of cotton lint samples, seed and seed linter, seedcotton samples, fibre, yarn and fabric samples are tabulated.

The CCLC roller contains $18,077 \mathrm{mg} / \mathrm{Kg}(\mathrm{ppm})$ to $30,780 \mathrm{mg} / \mathrm{Kg}(\mathrm{ppm}$ ) as total chromium (3 to $4 \%$ as total chromium). This included trivalent and hexavalent chromium. During the ginning operation, lint adsorbs chromium particles which contains $143 \mathrm{mg} / \mathrm{Kg}$ (ppm) to 1994 $\mathrm{mg} / \mathrm{Kg}(\mathrm{ppm})$. The CCLC roller is grooved at the start of each shift and filing or turning of the roller for leveling is done to get uniform diameter at start of each season. At that time, the wearing of roller is more and presence of chromium to the extent of 1994 $\mathrm{mg} / \mathrm{Kg}(\mathrm{ppm})$ with lint. The total weight of chromium removed during a cotton season of 16 hours per day is 450 to 600 grams per gin roller gin. The chrome specific dust from one ginning machine enters in to environment and being adsorbed in lint stage having the level of $143 \mathrm{ppm}$. The environmental standards for chromium in spun yarn is $2 \mathrm{ppm}$ and $\mathrm{Cr}$ (III) for baby clothing and fabric is $0.1 \mathrm{ppm}$ and nil for $\mathrm{Cr}$ (VI). The traces found contain hexavalent chromium being adsorbed from contaminated lint, yarn to fabrics and subsequently cannot be removed in fabrics. There is evidence that the toxic effects on humans due to $\mathrm{Cr}$ (III) and $\mathrm{Cr}$ (VI) of its carcinogenecity and corrosiveness. The analysis show that traces of $\mathrm{Cr}$ (VI) are found in even analar grade trivalent chromium compounds and complications do arise due to the reducibility nature of these traces that affect the organic tissues of the body. This regenerating effects occur rapidly and dependent of the worker dose and exposure time.

TABLE 1

RESULTS OF ROLLER WEAR OUT DATA

\begin{tabular}{|l|l|l|l|l|l|l|}
\hline \multirow{3}{*}{ M/c No. } & \multicolumn{6}{|c|}{ DIAMETER OF THE ROLLERS AFTER ONE SEASON IN mm } \\
\cline { 2 - 7 } & \multicolumn{3}{|c|}{ ROLLER SIDE 'A' } & \multicolumn{3}{c|}{ ROLLER SIDE 'B' } \\
\cline { 2 - 7 } & LEFT & $\begin{array}{c}\text { MIDDL } \\
\mathrm{E}\end{array}$ & RIGHT & LEFT & $\begin{array}{c}\text { MIDDL } \\
\mathrm{E}\end{array}$ & RIGHT \\
\hline 1 & 140 & 140 & 140 & 141 & 143 & 142 \\
\hline 2 & 140 & 140 & 140 & 140 & 142 & 142 \\
\hline 3 & 145 & 146 & 150 & 150 & 145 & 140 \\
\hline
\end{tabular}




\begin{tabular}{|l|l|l|l|l|l|l|}
\hline 4 & 153 & 153 & 153 & 148 & 148 & 148 \\
\hline 5 & 148 & 147 & 148 & 148 & 148 & 148 \\
\hline 6 & 146 & 147 & 148 & 146 & 146 & 146 \\
\hline 7 & 135 & 135 & 135 & 145 & 142 & 140 \\
\hline 8 & 140 & 140 & 140 & 145 & 142 & 140 \\
\hline 9 & 150 & 150 & 150 & 148 & 148 & 148 \\
\hline 10 & 138 & 136 & 136 & 136 & 136 & 136 \\
\hline 11 & 145 & 145 & 146 & 145 & 145 & 145 \\
\hline 12 & 136 & 136 & 136 & 136 & 136 & 136 \\
\hline 13 & 158 & 158 & 158 & 158 & 157 & 157 \\
\hline 14 & 160 & 160 & 160 & 161 & 160 & 160 \\
\hline 15 & 154 & 154 & 154 & 155 & 156 & 156 \\
\hline 16 & 155 & 155 & 156 & 155 & 154 & 154 \\
\hline 17 & 160 & 160 & 159 & 160 & 160 & 160 \\
\hline 18 & 160 & 160 & 161 & 160 & 161 & 166 \\
\hline
\end{tabular}

Initial diameter of the rollers $=180 \mathrm{~mm}$. Chromium roller compactness rate is -0.010 to $-0.050 \mathrm{~mm}$, i.e. -10 to $-50 \mu \mathrm{m}$ per hour. Wearing rate is $0.033 \mathrm{~mm} /$ hour and the percentage material removed per roller $43.8 \%$.

Table-2

Chromium Contamination Levels in Cotton and Its Products

Source: Chrome composite leather-clad(CCLC) roller $=18,077$ to $30,783 \mathrm{mg} / \mathrm{kg}$

Bio-availability for chromium uptake on cotton $=3 \mathrm{ppm}$

SI.No. Cotton and its Products Total Chromium Environmental Standards

${ }^{*}$ MOEF Notification -157

\begin{tabular}{|c|c|c|}
\hline 1. Lint cotton & 143-1990 ppm & $0.1 \mathrm{ppm}$ \\
\hline Spun yarns & $17-250 \quad \mathrm{ppm}$ & $0.1 \mathrm{ppm}$ \\
\hline Woven fabrics & $17-45 \quad \mathrm{ppm}$ & $0.1 \mathrm{ppm}$ \\
\hline
\end{tabular}



4. Cotton seeds
0-312 ppm
5. Edible oil
0-259 ppm
6. Oil cake
0-190 ppm
7 Linter
0-159 ppm

- * Ministry of Environment \& Forests Notification No.157, Dated 1 st May 1996.

Following are the significant findings of chromium in dust samples with relevant ecostandards:

TABLE-3

Chromium Level in Dust Samples

\begin{tabular}{clclc}
\hline $\begin{array}{l}\text { SI.No. } \\
\text { LD }_{50}\end{array}$ & Source of Dust & Total $\mathrm{Cr}$ & ${ }^{* *}$ Environmental Standards, \\
\hline 1. & Ginning point & $51-173 \mathrm{ppm}$ & $50 \mathrm{ppm}$ \\
2. & CCLC grooving point & $17-1994 \mathrm{ppm}$ & $50 \mathrm{ppm}$ \\
\hline
\end{tabular}

**U.S. National Institute of Occupational and Safety Hazard Standards, 1992

The manufacturing technology, design engineering features and assembly drawings show that the conventional fabric and rubber roller gin covering material is selected with the following characteristics, namely,

Hardness of 90 (type DO durometer),

9 to 10 layers of fabrics $20 \mathrm{~mm}$ length,

Thickness of fabrics $1.2 \mathrm{~mm}$,

The rubber compounding is resilient and

$0.76 \mathrm{~mm}$ of fibre bristles protrude beyond the rubber surface is maintained in spite of wear.

On the basis of the design and development of various rollers with subsequent performance evaluation studies, chrome-free RCF roller has been demonstrated with 
reference to techno-commercial and eco-friendliness in ginning industries. The newly developed RCF rollers are successful and effective in functioning and in ginning out the seed-cotton. Cost economics study reveals that eco-friendly RCF roller ginnery sounds better in all aspects with reference to environmental, cotton technological and techno-commercial aspects. Given below the table showing data of engineering analysis of eco-friendly cotton lint and chromium contaminated lint.

TABLE-5

DATA OF ENGINEERING ANALYSIS OF ECO-FRIENDLY COTTON LINT AND CHROMIUM CONTAMINATED LINT

\begin{tabular}{|c|c|c|c|}
\hline $\begin{array}{l}\text { Sl. } \\
\text { No. }\end{array}$ & PARTICULARS & $\begin{array}{l}\text { O-FRIENDLY GIN } \\
\text { OLLER/GINNED } \\
\text { LINT }\end{array}$ & $\begin{array}{l}\text { CHROME GIN } \\
\text { ROLLER / } \\
\text { GINNED LINT }\end{array}$ \\
\hline 1. & Seed Index & 7.07 & 7.34 \\
\hline 2. & Knife blunting & Every four days & daily \\
\hline 3. & $\begin{array}{l}\text { Grooving of gin roller } \\
\text { frequency period }\end{array}$ & Every five days & daily \\
\hline 4. & Power at No load, $400 \mathrm{~V}$ & $1.28 \mathrm{KW}$ & $1.6 \mathrm{KW}$ \\
\hline 5. & Power at Full load, 400V & $1.696 \mathrm{KW}$ & $1.92 \mathrm{KW}$ \\
\hline 6. & No load current & $4 \mathrm{~A}$ & $5 \mathrm{~A}$ \\
\hline 7. & Full load current & $5.3 \mathrm{~A}$ & $6 \mathrm{~A}$ \\
\hline 8. & Seed fuzz & $6.2 \%$ & $5.0 \%$ \\
\hline 9. & $\begin{array}{l}\text { Diameter reduction per } \\
\text { machine-hour }\end{array}$ & $37.89 \mu \mathrm{m}$ & $64 \mu \mathrm{m}$ \\
\hline 10. & $\begin{array}{l}\text { Production per } \\
\text { machine-hour }\end{array}$ & $38.26 \mathrm{~kg}$ & $36 \mathrm{~kg}$ \\
\hline 11. & $\begin{array}{l}\text { Expected useful life of } \\
\text { washer } \\
\text { (wearing up to } 30000 \mu \mathrm{m} \text { ) }\end{array}$ & 844 Machine-hour & 437.5 Machine-hour \\
\hline 12. & Friction of roller to lint & 0.768 & 0.123 \\
\hline
\end{tabular}


TABLE 6

HIGH VOLUME TESTS USING VOLUME INSTRUMENT FOR PHYSICAL PROPERTIES

\begin{tabular}{|c|c|c|}
\hline PARTICULARS & $\begin{array}{l}\text { ECO-FRIENDLY GIN } \\
\text { ROLLER/GINNED } \\
\text { LINT }\end{array}$ & $\begin{array}{l}\text { CHROME GIN } \\
\text { ROLLER / } \\
\text { GINNED LINT }\end{array}$ \\
\hline
\end{tabular}

13. $2.5 \%$ Span length

27.7

28.6

14. Tenacity, g/tex

$21.3 \mathrm{~g} / \mathrm{tex}$

$22.2 \mathrm{~g} / \mathrm{tex}$

15. Uniformity Ratio, UR\%

46

45

16. Short Fibres, $\%$

$3.5 \%$

$4.0 \%$

17. Color/grade/appearances Yellowish and

White shining,

Very good

poor

\section{SCANNING ELECTRON MICROSCOPE TEST}

18. Wax content proportion

$0.3 \%$

Nil

and better dye

Catching properties

Poor dye

Catch properties

19. Dye up-take

Very good

Poor

20. Scanning physical and

Very good chemical properties

21. $2.5 \%$ span length, $\mathrm{mm}$

35.6

35.4

22. Uniformity, $\%$

46.0

44.0

23. Baer sorter, Mean length,mm 32.3

24. Elongation

40.0

42.0

25. Short fibre, $\%$

14.6

16.4

26. Tenacity, g/tex

28.6

27.8

27. Micronnaire

3.0

2.8

28. $2.5 \%$ Span length, $\mathrm{mm}$

28.5

28.2

29. Uniformity Ratio, \%

47.0

47.2

TABLE -7 


\begin{tabular}{|c|c|c|}
\hline $\begin{array}{l}\text { S1. PARTICULARS } \\
\text { No. }\end{array}$ & $\begin{array}{l}\text { ECO-FRIENDLY GIN } \\
\text { ROLLER/GINNED } \\
\text { LINT }\end{array}$ & $\begin{array}{l}\text { CHROME GIN } \\
\text { ROLLER / } \\
\text { GINNED LINT }\end{array}$ \\
\hline
\end{tabular}

30. Short fibre, $\%$

6.2

5.2

31. Tenacity, g/tex

21.8

21.4

$(1 / 8$ "stello gauge)

32. Elongation

6.0

33. Micronnaire

3.4

3.3

34. Leaf

3.0

4.0

35. Area , $\%$

0.60

0.7

36. Trash Count

28

28

37. $\mathrm{Rd}$

67.7

67.8

38. $+\mathrm{b}$

14.5

14.5

39. Colour Grade

24.4

24.4

$40 \quad$ SCI

128.0

129.0

\section{Conclusions and Suggestions}

The CCLC rollers used in ginning industries get powdered during ginning operation and enter the environment as Chrome Specific Dust. It was observed that the chrome specific dust contaminates cotton and its products. The chromium contamination levels for cotton and its products were abnormal for all the samples except that the cotton samples obtained from RCF roller gin rollers i.e., eco-friendly ginning industries. As per the environmental standards (MOEF Notification No.157, 1996), chromium content in cotton and its products not to be more than $0.1 \mathrm{ppm}$. The samples, namely, lint cotton, yarn, fabrics, seed, linter, edible oil and oil cake were found contaminated and their levels were in the range of 110 to $1990 \mathrm{ppm}$ obtained from the source of dust-producing grinding CCLC rollers sample which contained 
18,077 to $30,783 \mathrm{ppm}$. The ginned lint cotton gets contaminated to an extent of 143 to $1990 \mathrm{mg} / \mathrm{kg}(\mathrm{ppm})$ of chromium and the woven fabrics to the tune of 17 to $45 \mathrm{ppm}$ of chromium against the safe limit of $0.1 \mathrm{ppm}$. The variations in concentration levels were because of the coating of chromium with fine dust particle and adsorption properties on to the cotton and its products. The chromium was not detected from RCF ginned lint cotton as there is no chromium in the source, which confines the eco-standards.

On the basis of the design and development of various rollers with subsequent performance evaluation studies, chrome-free RCF roller has been demonstrated with reference to techno-commercial and eco-friendliness in ginning industries. The newly developed RCF rollers are successful and effective in functioning and in ginning out the seed-cotton. Cost economics study reveals that eco-friendly RCF roller ginnery sounds better in all aspects with reference to environmental, cotton technological and techno-commercial aspects. This improved technology is amenable for commercialization to the industries.

Though the initial cost of the RCF roller is 11 times more than the life of CCLC roller, the high price is compensated, as it is durable upto an estimated life of seven years than more of a few months of CCLC rollers. Besides, it ensures the following advantages.

(1) There is negligible wear and tear and also zero maintenance,

(2) High ginning efficiency and output of about 1.25 times more than the CCLC rollers because the developed roller made up of rubberized cotton fabrics has a surface finish conducive to high ginning efficiency,

(3) $50 \%$ reduction in the weight of the rollers consume $25 \%$ less in energy consumption that is power saving of three times less compared to CCLC roller ginneries.

(4) It is observed that the noise level in eco-friendly ginneries is reduced to a range of 4 to $7 \mathrm{~dB}(\mathrm{~A})$ due to inherent properties and cushioning effects,

(5) Eco-friendly cotton and its products can be obtained.

(6) Labour output / $\mathrm{hr}$ is 2.4 standard performance rating, that is twice than CCLC ginneries because of cleaner environment.

(7) Medical charges for treating the affected workers decrease manifold. 
The newly designed and developed eco-friendly ginneries eliminate chromium contamination and pollution from cotton ginning industries. These give rise to control at-source pollution control, such that the industries meet the requirement of environmental standards being enforced by many countries and high quality yarns and fabrics meeting international standards be produced. The industries will be free from chrome-related contamination and pollution problems, occupational and nonoccupational health hazards. The ginneries have been tested commercially and found better in all aspects with reference to cotton technological parameters, dye-catching properties, physical and chemical properties. It could be successfully used commercially as an improved alternative in cotton ginning industries for the cleaner environment with benefits to society, industry owners, traders, workers, employees and the Government.

\section{Recommendations}

1. Most of the cotton ginning operations are done by using DR gins in India, Africa, Tanzania and Egypt. The lint cotton and cotton seeds processed through these chrome roller ginneries are contaminated. It is imperative that a policy decision can be taken to do away these rollers and get replaced with ecofriendly rollers, and

2. Industry, Government and Regulator should come forward to subsidize this venture in view of its demonstrated and proven techno-commercial feasibility in connection with eco-friendliness.

3. Most of the cotton ginning operations are done using roller gins in India, Africa, Tanzania and Egypt. Out of the lint obtained from these CCLC roller ginneries in this countries, it is quite important to appreciate the fact that the lint so produces is contaminated with chromium powder produces deleterious effect on the people working in the vicinity. Yarn and seed obtained is also contaminated with chromium. Toxic effects are produced by prolonged contact with airborne or solid or liquid chromium contamination and pollution even in small quantities. Hence, it is imperative that a policy decision be taken to replace the presently used CCLC rollers with eco-friendly rollers or vegetable tanned leather rollers. 


\section{Acknowledgements}

The authors are thankful to Director, Indian School of Mines, (Deemed University), Branch I.I.T., Dhanbad - 826 004, India for giving permission to publish this research paper. The Authors are also thankful to Mr. Shrish R. Shah, Member, Indian Cotton Development Council, (ICDC), Ministry of Agriculture(Govt. of India) who have sponsored this research project.

The author of this research paper is thankful to FACULTY DEVELOPMENT BUREAU OF ALL INDIA TECHNICAL EDUCATION, New Delhi for awarding the prestigious faculty-specific AICTE EMERITUS FELLOWSHIP DURING 2005-2008.

The first author is also thankful to World Scientific and Engineering Academic and Society (WSEAS), Athens, Greece for the award of Post Doctoral Research Fellowship during the year 2006.

\section{References}

1. Bandyopadhyay, K. and Gangopadhyay, A. and Son, N.N. (2000). "Adsorption Study on Fly Ash as a Waste Resource for the Removal of Chromium."

World Congress on Sustainable Development Proceedings, Vol. I, pp. 532-539,

2. Gillum, N., Marvis. (1964). “ Properties of Roller Covering Materials”, United States Department of Agriculture (USDA), Technical Bulletin No.1490, Washington: pp.1-45, 1994.

3. Morton Lippman. (1991). "Book on Asbestos and Mineral Fibres."

Elsevier Publishers, pp. 34-134, 1991.

4. Rao, C.S. (1995). "Book on Environmental Pollution Control Engineering." Wiley Eastern Ltd., pp. 1-79, March, 1995.

5. Rao, M.N. and Rao, H.V.N. (1989). "Book on Air Pollution." Tata McGraw Hill Publishing Co.Ltd., New Delhi, pp.35-56, 1989.

6. Reference No. 157, MOEF Notification No.157, dated 4.5.1996.

7. Shete,D.G. and Sundaram ,V. (1993). "Some Practical Hints for Better Ginning of Cotton with Roller Gins.” ICMF Journal, October, 1983.

8. Shirley Institute "Research Encyclopaedia-II." Manchester, Cotton Dust Hazards, Textile Series Memories, pp. 23-56, 1982.

9. Sujana, M.G. and Rao, S.B. (1997). "Unsafe Chromium.” Science Reporter, pp.27-30, Sep.1997.

10. Townsend J.S. Walton T.C. and Martin J. (1940) Roller Gin Construction, 
Operation and Maintenance, U.S. Department of Agriculture,

Washington, USA.

11.U.S. National Institute of Occupational and Safety Hazard Standards, 1992

12. Vijayan Iyer G., 1994, Study of Backlash in Double Roller Gins, The Cotton Gin and Oil Mill Press, Texas, USA

13. Vijayan Iyer, G. (1999). "Cotton Ginning and Lint Quality." Indian Textile Industry and Trade Journal, pp 73-80, 1999.

\section{PLATE-1; COTTON ROLLER GINNING MACHINE;}

Front- Single Roller (SR) Gin ; 
Rear - Double Roller (DR) Gin.

PLATE-2 ; CHROME COMPOSITE LEATHER-CLAD

WASHERS USED FOR MAKING CCLC ROLLER GIN ROLLERS 


\section{PLATE-3 : FILLED AND PRESSED CCLC WASHERS ASSEMBLED IN THE FORM OF A ROLLER OF DR GIN}


PLATE-4;OPERATION OF GIN ROLLER EXPERIMENTATION DEVICE (GRED) ASSEMBLED WITH RUBBERIZED COTTON FABRIC ROLLER 


\section{PLATE-5; POLLUTION-FREE RUBERIZED COTTON FABRIC (RCF) CHROME LESS WASHERS FOR MAKING RCF ROLLERS OF ROLLER GINS}


PLATE-6; PILOT MODEL ROLLER GIN ASSEMBLED WITH POLLUTION-FREE RUBBERIZED COTTON FABRIC (RCF) CHROMELESS ROLLERS WHILE IN OPERATION 
PLATE-7; ECO-FRIENDLY GINNED LINT COTTON FROM RCF ROLLER GINNERIES 
PLATE-8; TRIAL COMMERCIAL PRODUCTION FOR COMMERCIALIZATION 